〈報 告〉

\title{
二酸化塩素ガス放散製剤のインフルエンザウイルス不活化および 黄色ブドウ球菌殺菌能の検証一低湿度環境表面での検討一
}

西村 秀一

\section{Evaluation of Virucidal and Bactericidal Abilities Claimed to Be Exhibited by a Chemical Product against Influenza Virus and Staphylococcus aureus on the Environmental Surface under Low-humidity Condition}

\author{
Hidekazu NISHIMURA
}

Virus Research Center, Clinical Research Division, Sendai Medical Center, National Hospital Organization

(2017 年 1 月 10 日受付 $\cdot 2017$ 年 2 月 27 日受理)

\begin{abstract}
要 旨
ウイルスの不活化や殺菌効果を標榜する, 据え置き芳香剂型の剂型で二酸化塩素ガスを放散させ る製品の, 環境表面上の病原体に対する同効果の有無を検証した. 本邦の冬の生活空間を想定した 室温 $20^{\circ} \mathrm{C}$, 相対湿度 $25 \%$ の密閉空間を, 製品から放出されたガス濃度が $0.03 \mathrm{ppm}$ になるよう調 整した，その中に，スライドグラスの上に一定量の A 型インフルエンザウイルス溶液あるいは Staphylococcus aureus 菌液を滴下し短時間で自然乾燥したものを置き, 2 時間後に回収し一定量 のメディウムで洗い流し, 活性ウイルス量や生菌数を測定した. その結果, 当該条件下でガスの曝 露を受けた検体での活性ウイルス/生菌量は, 曝露のない対照のそれと変わらなかった.
\end{abstract}

Key words : 二酸化塩素ガス, 環境表面, ウイルス不活化, 殺菌, 冬季生活空間

\section{はじめに}

抗菌，抗ウイルス効果を標榜する種々の製品が市販さ れている。 だが，それらは，実用上その効果が中立的に 検証され証明されていないことが多い。我々は，これま で空中浮遊イオンや特殊粒子の放散により空中浮遊イン フルエンザウイルスに対する不活化を標榜するいくつか の電気製品について実際の効果の有無を検証し, 標榜さ れているような能力がほとんどないことを報告してき た ${ }^{1)}$.さらに先行研究で我々は, 二酸化塩素 (以下 $\left.\mathrm{ClO}_{2}\right)$ を空中に放散させ，空中浮遊インフルエンザウイルスに 対する不活化の効果を標榜する据え置きボトル型の薬剤 についても検証し, その結果, 本邦でインフルエンザが 流行する冬季の生活空間あるいはそれに近い温湿度条件 下では, 製品から出される $\mathrm{ClO}_{2}$ に空中に浮遊させたイ ンフルエンザウイルスに対して，生活に支障ないと思わ れる濃度以下では不活化効果が認められなかったことを，

独立行政法人国立病院機構仙台医療センター臨床研究部ウイルス センター
報告している.

この種の製品に関しては，ときに行政が消費者に対す る不利益を警告している゙ らの感染制御に使えないかという問いあわせ4) も，少な からずある。そうした現場での感染制御においては，手 洗いが強く推奨されているのはもちろんのこと, それと ならんで環境消毒も重要な位置を占めている. 今回我々 は，患者の咳あるいはクシャミに由来する落下し環境に 付着した大飛沫を想定し, そのモデルとしてインフルエ ンザウイルスを含む液滴を，また環境に普通に存在する 細菌としての Staphylococcus aureus を含む液滴を，ス ライドグラスに滴下し, それらの乾燥残椬を, 冬季の生 活空間あるいはそれに近い温湿度条件下の密閉空間で当 該製品の出す $\mathrm{ClO}_{2}$ に暴露させ, ウイルス不活化/殺菌効 果の有無を検証したので，その結果を報告する.

\section{材料と方法}

この種の製品で一般に入手可能なものは, 2010 年の 時点で 9 社の製品があったが ${ }^{3}$, 今回も前回の報告同様, 

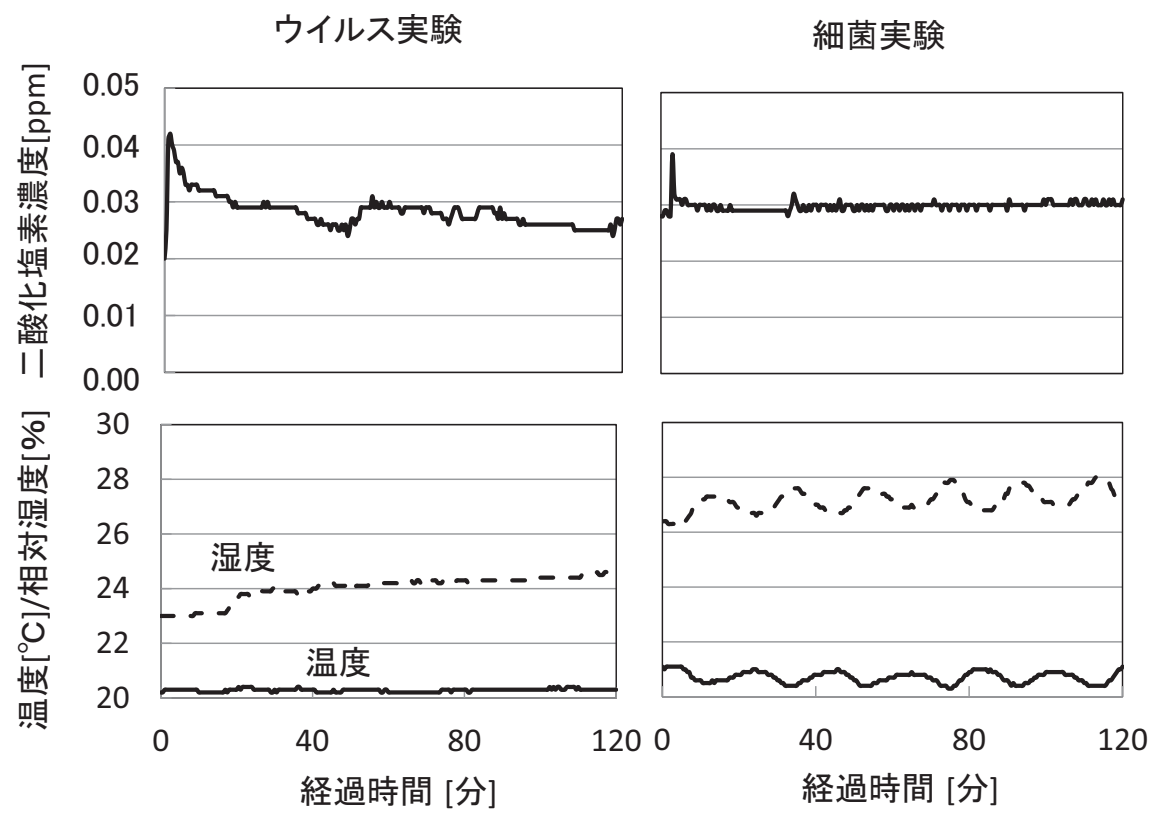

図 1 実験空間の温度と相対湿度環境，ならびに二酸化塩素ガス濃度

チャンバー内濃度 $0.03 \mathrm{ppm}$ を目標に製品の蓋の開閉により調整してえられた実際の濃度とチャ ンバー内で測定された温度と相対湿度の時間的推移

それらの中の最大手で, 自社による種々の実験論文 ${ }^{5}$ や その使用に基づく感染制御の報告6.7) 等の発表が多数な されているクレペリン Gゲル $60 \mathrm{~g}$ （大幸薬品）を検証 に用いた。

人工的に温度や湿度を調整するための容積 $25 \mathrm{~m}^{3}$ の密 封クリーンブースの中を, 冬季の室内を想定した温度 $20^{\circ} \mathrm{C}$ ，相対湿度 $23 \%$ を目標に調整し，その中で同製品 を開封し, 試験中の同空間内の $\mathrm{ClO}_{2}$ 濃度を $0.03 \mathrm{ppm}$ に 維持することを目標に, $\mathrm{ClO}_{2}$ 測定器 (インタースキャ ン社（CA, USA）モデル 4330-1000b）で濃度をモニター しつつ, 必要に応じてパスボックス越しに製品の蓋を開 閉させるやり方で, 手動調整した。

ウイルスは, 先行報告と同じく材料をひとつの実験室 株ウイルスに代表させ ${ }^{1.22}$, 発育鷄卵尿膜腔で増殖させた $\mathrm{A} /$ 愛知 $/ 2 / 68$ (H3N2) 株インフルエンザウイルスを含 むしょう尿液（蛋白質濃度 $1 \mathrm{wt} \%$ ）を用いた。一方, 細 菌の方は, ごく一般的に環境中に存在する細菌である Staphylococcus aureus の, 当研究室で保存している実 験用ストックを用いた。

ウイルス液を $0.5 \mu \mathrm{L}$ ずつ 2 滴（約 $1 \times 10^{6}$ Plaque Forming Unit（PFU）相当）をスライドグラス上に滴 下させそのまま乾燥した残椬を実験空間内で 2 時間経過 させた後, $1 \mathrm{~mL}$ のウイルス培養用 MEM メディウムと ラバーポリスマンを用いて洗い流し, 回収した洗い液中 の活性ウイルス数を, MDCK 細胞を用いたプラーク法 で定量した。また, Staphylococcus aureus のブイヨン 溶液を $0.5 \mu \mathrm{L}$ ずつ 4 滴（約 $2 \times 10^{6}$ Colony Forming Unit
相当）スライドグラス上に滴下しそのまま乾燥した残渣 を実験空間内に置き， 2 時間経過後に $1 \mathrm{~mL}$ の細菌培養 メディウム（Q-Bio gene 社製 Circlegrow）とラバーポ リスマンを用いて洗い流し, 回収した洗い液中の生存細 菌数を, 普通寒天平板上に形成されるコロニーの数を指 標に測定した ${ }^{8}$.

\section{結果}

本実験は，インフルエンザの流行期である冬季の，暖 房された小さな室内を想定した容積 $25 \mathrm{~m}^{3}$ の密閉空間で 実施した，実験空間の実際の気温，相対湿度はそれぞれ 20.0-21.0 $\mathrm{C}, 23.0-28.0 \%$ の範囲であった（図 1)。同製品 は, 開封直後はガスが出にくく, 約半日 $25 \mathrm{~m}^{3}$ チャンバー 内に蓋を全開にした状態で放置した後にやっとガスの放 出が安定し始め, その後 2 時間で空間濃度 $0.03 \mathrm{ppm}$ に 達した。その時点で実験を開始し，その後実験時間中， それに近いレベルを維持することができた（図 1).

環境表面上に落ちたウイルス飛沫を想定してスライド グラス上に滴下したウイルス液乾燥残渣を上述空間で製 品由来の $\mathrm{ClO}_{2}$ のガスに 2 時間曝露後, $1 \mathrm{~mL}$ のメデイウ ムで洗い出された活性ウイルスの数を測定した。 その結 果, 対照では滴下した約 $1 \times 10^{6} \mathrm{PFU}$ のウイルスのうち 約 $10 \%$ にあたる $7.5 \times 10^{4} \mathrm{PFU}$ の活性ウイルスが回収さ れた，その一方， $0.03 \mathrm{ppm} の \mathrm{ClO}_{2}$ ガスへ曝露を 2 時間 経たものも, 回収された活性ウイルス量はガス非曝露対 照のそれと変わらなかった（表 1).

環境表面に存在する細菌を代表して, 通常の環境で普 
表 1 環境表面付着ウイルス/細菌に対する, 冬季室内環境相当温度・相対湿度条件下での, $0.03 \mathrm{ppm}$ 二酸化塩素 2 時間曝露の影響の有無の検討

\begin{tabular}{cccc}
\hline \multirow{2}{*}{ ウイルス*1/細菌*2 } & \multirow{2}{*}{ 滴下量 } & \multicolumn{2}{c}{ 回収量*3 } \\
\cline { 3 - 4 } & & 対照 & 曝露後 \\
\hline *1 Influenza virus $\mathrm{A} /$ 愛知 $/ 2 / 68(\mathrm{PFU}) \times 10^{4}$ & $9.2 \times 10$ & $7.5 \pm 1.7$ & $7.5 \pm 1.6$ \\
${ }^{2}$ Staphylococcus aureus (colony count) $\times 10^{6}$ & 2.8 & $2.0 \pm 0.7$ & $1.6 \pm 0.7$ \\
\hline
\end{tabular}

*3 独立した 3 回の実験の平均値土標準偏差

通に見られるStaphylococcus aureus の浮遊液をグラス 上に滴下し，同様の実験を行った。その結果，暴露 2 時 間後の Staphylococcus aureus の回収量も，対照とほと んど同じであった（表 1).

\section{考察}

本実験における $\mathrm{ClO}_{2}$ への曝露時間は，空中浮遊ウイ

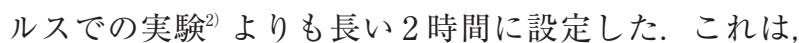
活性を保っているタイムスパンの短い空中浮遊状態のウ イルスにくらべて，環境表面付着状態のウイルスや細菌 の方が, より長い時間, 活性が維持され, あるいは生存 するためであった。 また環境における存在の仕方とその 制御を考えた場合にも, 污染から極めて短かい時間では なく，長い時間を想定すべきと考えたためでもある。

一方, $\mathrm{ClO}_{2}$ の空間濃度については, 先行実験と同じ 0.03 ppm に設定した2). これは, Ogata らがマウスを用いた 感染防御実験論文 ${ }^{5)}$ の中で，対照群に比べて有意にマウ スの死亡を防いだと報告している濃度であり，またこれ 以上は同ガス特有の臭いに不快感を持つ人も多く ${ }^{3)}$, こ れが実用の上での濃度限界と考えられたからである。

$\mathrm{ClO}_{2}$ はガス状の物質であるが，それが水に溶けた溶 液にはラジカルによる酸化効果があり, 細菌やウイルス の殺菌/不活化に有用であることが知られており，ガス 状の $\mathrm{ClO}_{2}$ にもその作用が期待されている ${ }^{9}$. だが，それ らの効果を発揮するためには, 濃度を含む適切な条件の もとで使用される必要がある ${ }^{9)}$.

本研究によって, 少なくともインフルエンザが流行す る冬季の室内生活空間を想定した温度・湿度環境下では, 使用された程度の低濃度 $\mathrm{ClO}_{2}$ ガスには, 環境表面上に 付着した状態のインフルエンザウイルスの不活化や黄色 ブドウ球菌に対する殺菌の効果は, ほとんどないことが 明らかになった. $0.03 \mathrm{ppm}$ で効かないものは, それ以 下の濃度でも効かないのは自明であろう。先の我々の, 空中浮遊ウイルスに対してまったく効果がないとした報 告とあわせれば，冬の室内環境のような使用環境では， 空中浮遊あるいは環境表面付着のいずれの形でのウイル スの存在に対しても, 当該製品がつくり出す $0.03 \mathrm{ppm}$ 程度の濃度での $\mathrm{ClO}_{2}$ には, 謳われている効果はほとん ど期待できないことが示されたことになる。

一方，本製品の感染制御への応用として紹介されるこ
との多い Ogata ら ${ }^{6)}$ および三村7) らによるインフルエン ザ様疾患に対する介入予防試験では, 感染防止効果が あったとされている，だがこれらはともに，製品を用い た介入群と対照の非介入群の参加者に関し，さまざまな 生活背景を考慮した公平な割り振りが厳密になされてお らず，また，介入期間も生活時間のごく一部に過ぎず, 生活の大半を占める非介入時間におけるインフルエンザ ウイルスへの曝露の影響の方が介入時間におけるそれよ りずっと大きいと思われるスタディであった。ささらに介 入した環境のガス濃度のデータも，論文には記載がない ものの極めて低いことは容易に推測され，何らかの交絡 現象を見ているものと推察せざるを得ない. 今回とりあ げた製品に限らず，揮発で生じさせた $\mathrm{ClO}_{2}$ による殺菌 やウイルス不活化を標榜し，またそれによって感染の阻 止の効能を示唆・宣伝する製品の効果の一方的説明につ いては，読み手側の注意が必要であろう。それとともに， 中立的立場から科学的に十分に吟味された検証をつづけ ていくことも，大事であろう.

謝 辞 : この場を打借りして, 本研究に協力してくれた仙台医 療センター臨床研究部ウイルスセンターの職員と客員研究員諸氏 に深謝いたします。

利益相反自己申告：申告すべきものなし．

文献

1）西村秀一：高性能の空中浮遊インフルエンザウイルス不活 化を謳う市販各種電気製品の性能評価. 感染症誌 2011; 85: 537-9.

2) 西村秀一：ウイルス不活化効果を標榜する市販据置き型二 酸化塩素ガス放散製剂の, 冬季室内空間相当の温湿度での 空中浮遊インフルエンザウイルス不活化の実用性の有無の 検証. 環境感染誌 2016; 31: 310-3.

3）国民生活センター：二酸化塩素による除菌をうたった商 品一部屋等で使う据置タイプについてー：http://www.kok usen.go.jp/news/data/n-20101111_1.html : 2016 年 11 月 11 日現在.

4）尾家重治：二酸化塩素ガスによる環境消毒の是非, 滅菌 消毒, 質疑応答. 日本医事新報 2008; 4385: 98.

5) Ogata N, Shibata T: Protective effect of low-concentration chlorine dioxide gas against influenza A virus infection. J Gen Virol 2008; 89: 60-7.

6) Ogata N, Shibata T: Effect of chlorine dioxide gas of extremely low concentration on absenteeism of school children. Int J Med Medical Sci 2009; 1: 288-9. 
7）三村啓司, 藤岡高弘, 三丸敦洋 : 環境感染誌 2010; 25: 27780.

8）西村秀一：殺菌能力を詔う各種空気洗浄電気製品の, 塗布 乾燥状態の細菌に対する効果の有無の検証．環境感染誌 2012; 27: 342-5.

9) US Department of labor: OSHA Chlorine dioxide: https:// www.osha.gov/dts/chemicalsampling/data/CH_226600.ht ml. accessed April 19, 2016.

〔連絡先：邓983-8520 仙台市宮城野区宮城野 2-8-8 仙台医療センター・ウイルスセンター 西村秀一 E-mail: hide-nishimura@mte.biglobe.ne.jp]

\title{
Evaluation of Virucidal and Bactericidal Abilities Claimed to Be Exhibited by a Chemical Product against Influenza Virus and Staphylococcus aureus on the Environmental Surface under Low-humidity Condition
}

\author{
Hidekazu NISHIMURA
}

Virus Research Center, Clinical Research Division, Sendai Medical Center, National Hospital Organization

\section{Abstract}

Reliability of a commercially available chemical product sold in Japan that has been claimed to inactivate viruses and kill bacteria on the environmental surface by releasing chlorine dioxide gas was investigated.

The aliquots of the viral fluid of influenza A/Aichi/2/68 strain virus propagated in the allantoic fluid of fertilized hens' eggs and the bacterial fluid of Staphylococcus aureus stock solution were poured on a glass slide as two and four droplets of $0.5 \mu \mathrm{L}$ each, respectively, and placed in a $25 \mathrm{~m}^{3}$-space closed environment, with the temperature and relative humidity set at about $20^{\circ} \mathrm{C}$ and $25 \%$, respectively, which resemble room conditions during the winter season. The concentration of the gas was manually adjusted at about $0.03 \mathrm{ppm}$ by opening and closing the bottle cap. After $2 \mathrm{~h}$, the dried-up remains of the droplets on the glass were washed out with $1 \mathrm{~mL}$ of viral culture medium or bacterial broth, and the amounts of the active virus and the living bacteria in the washing fluid were titrated using plaque or colony assays, respectively. The amounts of the active viruses and living bacteria were similar in the washing fluids from both the gas-exposed and the control slides, indicating that the gas had no virucidal and bactericidal activities under these conditions.

Key words: Chlorine dioxide, environmental surface, virucidal activity, bactericidal activity, winter season 